UDC 681.5:519.2:622.778

I. K. Mladetsky ${ }^{1}$, Dr. Sc. (Tech.), Prof., orcid.org/0000-0002-6159-6819,

Ya. G. Kuvaiev ${ }^{1}$, Cand. Sc. (Tech.), Assoc. Prof., orcid.org/0000-0003-4981-346X,

N. S. Pryadko ${ }^{2}$, Dr. Sc. (Tech.), Senior Research Fellow, orcid.org/0000-0003-1656-1681
DOI: $10.29202 /$ nvngu/2018-4/6

1 - National Mining University, Dnipro, Ukraine, e-mail: kuvaievig@gmail.com

2 - Institute of Technical Mechanics National Academy of Sciences of Ukraine and State Space Agency of Ukraine, Dnipro, Ukraine

\title{
THE CONTROL REGULARITY DETECTION OF THE USEFUL MINERAL EXTRACTION FROM THE ORE FEED STREAM WITH AUTOGENOUS GRINDING. PART 1. CORRELATION ANALYSIS
}

Purpose. For an operator exception out of a concentration process control circuit to identify the patterns that determine the indicative events characterizing the process state along the control channel "useful mineral content in the ore -useful mineral content in a concentrate" in an ore-concentrating plant with autogenous grinding (AG).

Methodology. Correlation analysis of the control object parameters: the technological process at the concentrating plant with AG.

Findings. According to the type and parameters of the correlation functions between the useful mineral content in the feedstock and concentrate, a number of indicative events characterizing the process state along the control channel "useful mineral content in the ore - useful mineral content in the concentrate" were identified.

Originality. The control regularities of concentration process control by comparing the numerical values of the decay time and the equivalent retardation of the autocorrelation and correlation functions of the total iron content and the time constant of the technological line with AG are revealed for the first time.

Practical value. The obtained results can be used to construct an automatic system for situational management of ferrous and non-ferrous ores concentrating process, both at separate sections with AG, and at plants including these sections.

Keywords: automation, indicative events, situational management system, iron ore dressing, ore concentrating factory with autogenous grinding

Introduction. Difficulty in concentrating process control consists in their random and unsteady character. The dressing technology devices are objects with variable parameters and, moreover, with random parameters. In the case of AG for the useful mineral disclosure additional difficulties create feedback between the dressing stages. At Ukrainian plants for all dressing sections operators determine the choice of vector components of the controlling influences, their values and the issuing moment on control channel "useful mineral content in ore - useful mineral content in a concentrate". For their exception from a control circuit it is necessary to understand response of a control object to the change in controlling influence values.

Analysis of the recent research and publications. The development of proven solutions for determining the level of AG mill loading with material, needed to be reduced in size, does not make it possible to completely eliminate the operator from the control circuit of the grinding cycles. This problem is attempted to be solved through the integrated use of several indirect methods for determining the mill load with AG, while simultaneously using the "intelligent" pressure sensors indication in centralized oil-lubrication systems of the two supporting bearings of the feeding and unloading mill pins and the acoustic characteristics of the noise emitted by the crushed material [1].

Systems are proposed where, for the same purposes, the stabilization circuit of the mill material reserve is

(C) Mladetsky I. K., Kuvaiev Ya. G., Pryadko N. S., 2018 used according to the power sensor consumed by in-line mill engine and the stabilization circuit of mill material reserve by its weight [2].

The closed AG cycle management is based on the interaction of automatic control systems (ACS) of ore consumption into the mill, the ratio of solid to liquid in the mill discharge port and the classifier discharge density $[2,3]$. This architecture allows acting without an operator's intervention only within narrow limits, caused by the crushed material properties instability. Namely, the last factor causes the operator's intervention to change the local ACS tasks.

System designers understood this and made further steps in the direction of using the AG process model [4] or expert systems, and mainly, their joint use to exclude the operator from the control circuit [5]. The authors of the article obtained positive application results of the correlation analysis of the ore concentrating plant (OCP) operation with ball grinding for the indicative event determination characterized the process state along the control channel "useful mineral content in the ore - useful mineral content in the concentrate" [6]. Moreover, a retrospective review of the Russian segment state of mining management systems in ferrous metallurgy [5] is indicative and fully corresponds to the Ukrainian mining and processing enterprises state.

Unsolved aspects of the problem. To build the expert part of the OCP automatic control system (ACS) with $\mathrm{AG}$, it is necessary to determine the indicative events characterized the process state along the control channel "useful mineral content in the ore - useful mineral con- 
tent in the concentrate". This allows the OCP automatic control system to "understand" the control object response to the control action value change under the conditions of the permanent grinding ore property changes.

Presentation of the main research and explanation of scientific results. To extract a useful mineral from ore flows with AG Ukrainian mining processing plants (MPP) use technological schemes with the following features (Fig. 1):

- within one ore concentrating plant at least ten similar sections work in parallel;

- at each dressing stage a finite number of operations are performed: opening (Fig. 1, block 1), screening (Fig. 1, block 2), separation (Fig. 1, block 3), extraction (Fig. 1, block 4) of a useful mineral (separation according to the useful mineral content), desliming (Fig. 1, block 5) and filtration of the saleable concentrate (Fig. 1, block 6);

- feedbacks on material flows cross the boundaries of individual dressing stages.

The initial ore arrives from the bunker, saleable concentrate is transported to a warehouse, and rejects are transferred to the rejecting storage.

Just as for OCP-1 (ball mill grinding) [6], the initial ore comes from the bunker, the saleable concentrate is transported to the warehouse, and the rejects are pumped to the rejecting storage.

This research is based on the data obtained from the results of normal technological testing of all sections of
Ore Concentrating Plant No. 2 (OCP-2) with AG of Inhulets Mining and Processing Plant (InMPP) under the conditions of stationary season (summer). The observation duration is five days, the discreteness is one hour. In total, more than 1450 values for each of the following technological parameters were obtained: ore processing $(t)$, production $(t / h)$, concentrate output $(\%)$, moisture in concentrate $(\%)$, total iron content $(\%)$, magnetic iron content in ore $(\%)$, total iron content in concentrate $(\%)$, total iron losses in rejects $(\%)$, loss of magnetic iron in rejects $(\%)$,extraction of magnetic iron in rejects (\%), extraction of total iron in concentrate (\%).

The obtained initial data has the following features:

- the input of all OCP-2 sections is fed with the original ore with the same useful mineral content;

- the content of total and magnetic iron in the rejects is determined to be the same one for all sections: at the place of their final mixing;

- the total iron content in the concentrate is determined for each section;

- during the period of information collection OCP-2 was idle for five hours, therefore each series of observations consists of two observation series: 64 and 43 respectively;

- in addition to the total idle hours of OCP-2, due to reasons beyond our control, there are no data of total iron content in the concentrate in the first observation series for sections No. 3 and No. 10 for 9 and 11 hours respectively, and also for the first 4 hours for the second series for section No. 1.

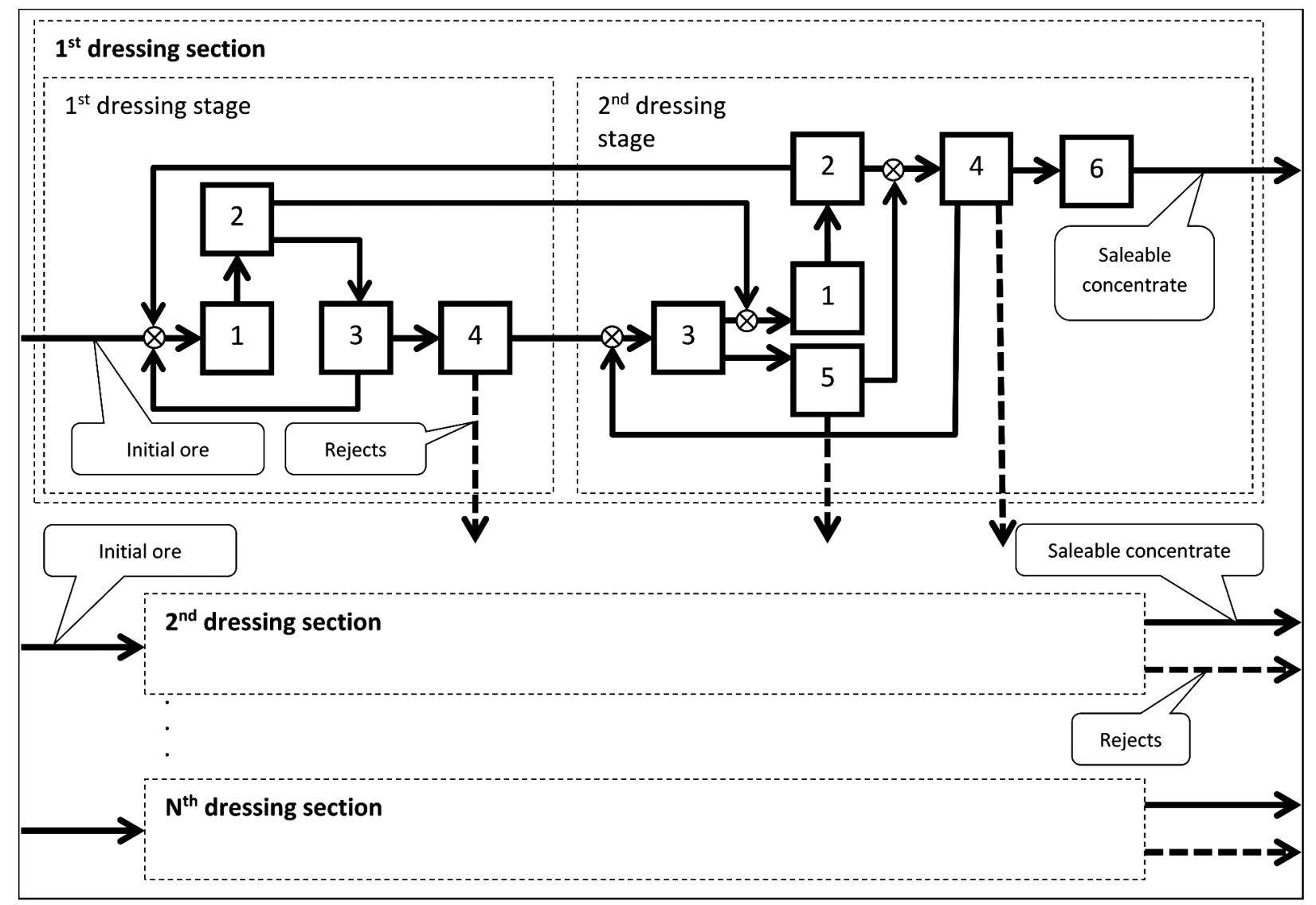

Fig. 1. Flow chart of the OCP ore flows with $A G$ 
Based on these data, there were constructed the autocorrelation functions of the total iron content in the initial ore $(\alpha)$ (Fig. 2), in the concentrate ( $\beta$ ) (Fig. 3) at the output of each section, in the rejects ( $v)$ (Fig. 2) and the correlation functions $\omega$ of the total iron content in the concentrate from its content in the initial ore for each section (Fig. 4). This allowed evaluating the main parameters and distribution laws of the decay time and the equivalent retardation of the autocorrelation and correlation functions of the useful mineral content in the ore fed flow of the OCP-2 (Fig. 5).
The decay time of the autocorrelation function of the total iron content in the initial ore (Fig. 2) is 22 for the first series $\left(K_{S 1 \alpha}\right)$ and 5 hours for the second series $\left(K_{S 2 \alpha}\right)$. For rejects this value is not determined for both observation series, since the autocorrelation functions have never crossed the abscissa axis over the all observation period. This circumstance indicates that the presented indicators cannot be attributed to the considered observation totality. They must be excluded from consideration.

For the first observation series the minimum decay time of the autocorrelation function of the total iron

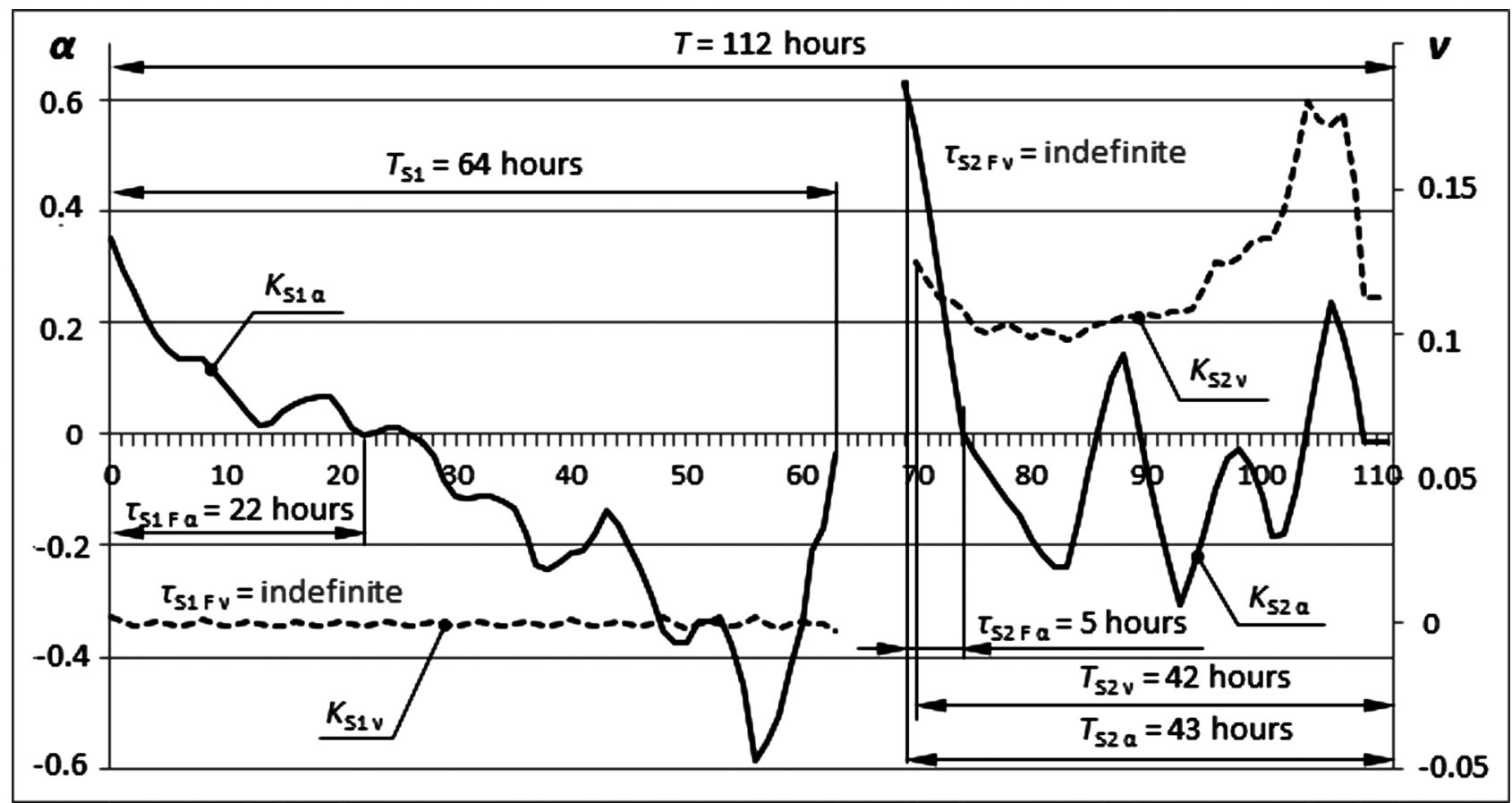

Fig. 2. Autocorrelation functions of the total iron content in the initial ore and rejects

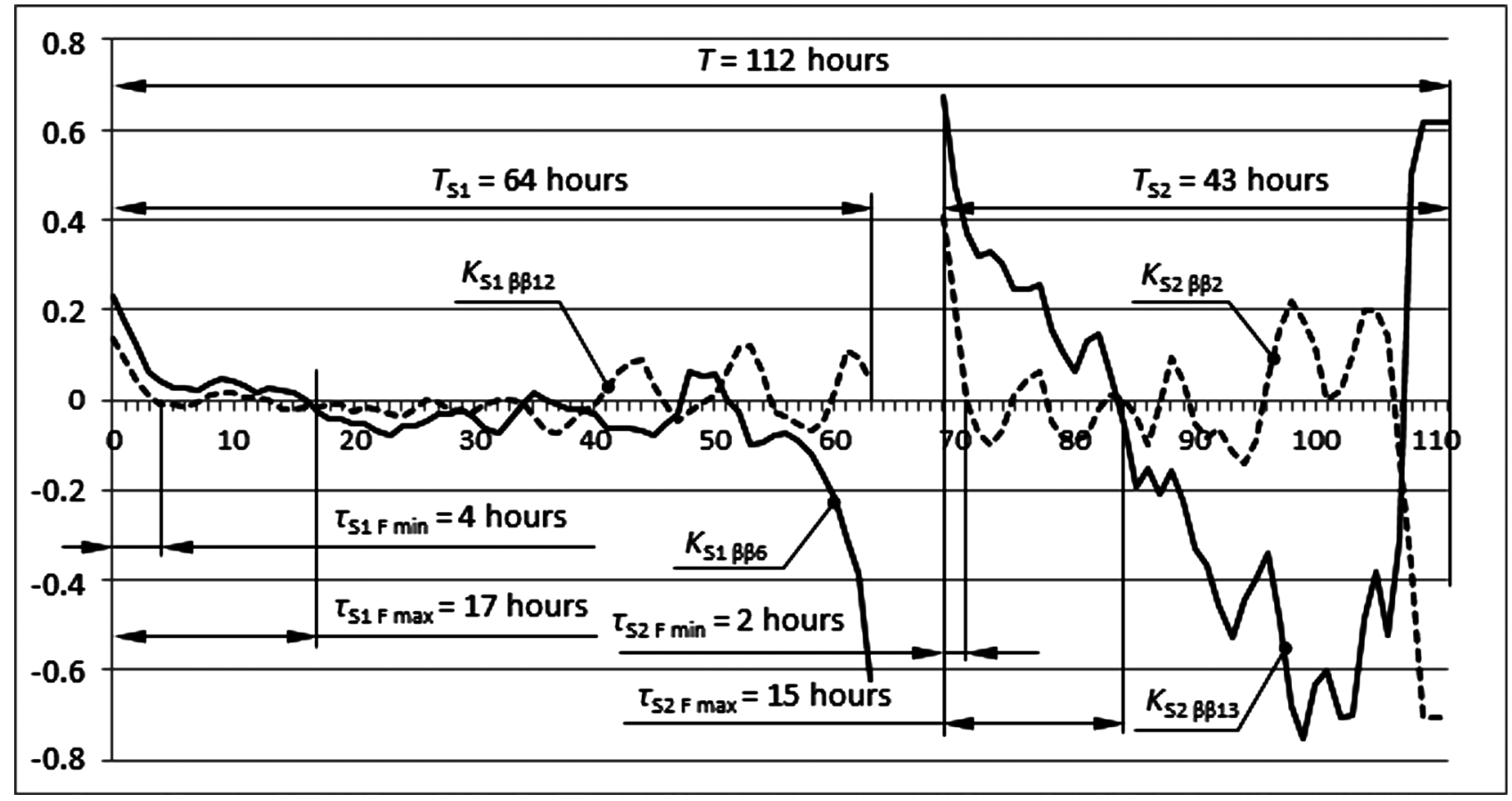

Fig. 3. Autocorrelation functions of the total iron content in the concentrate 


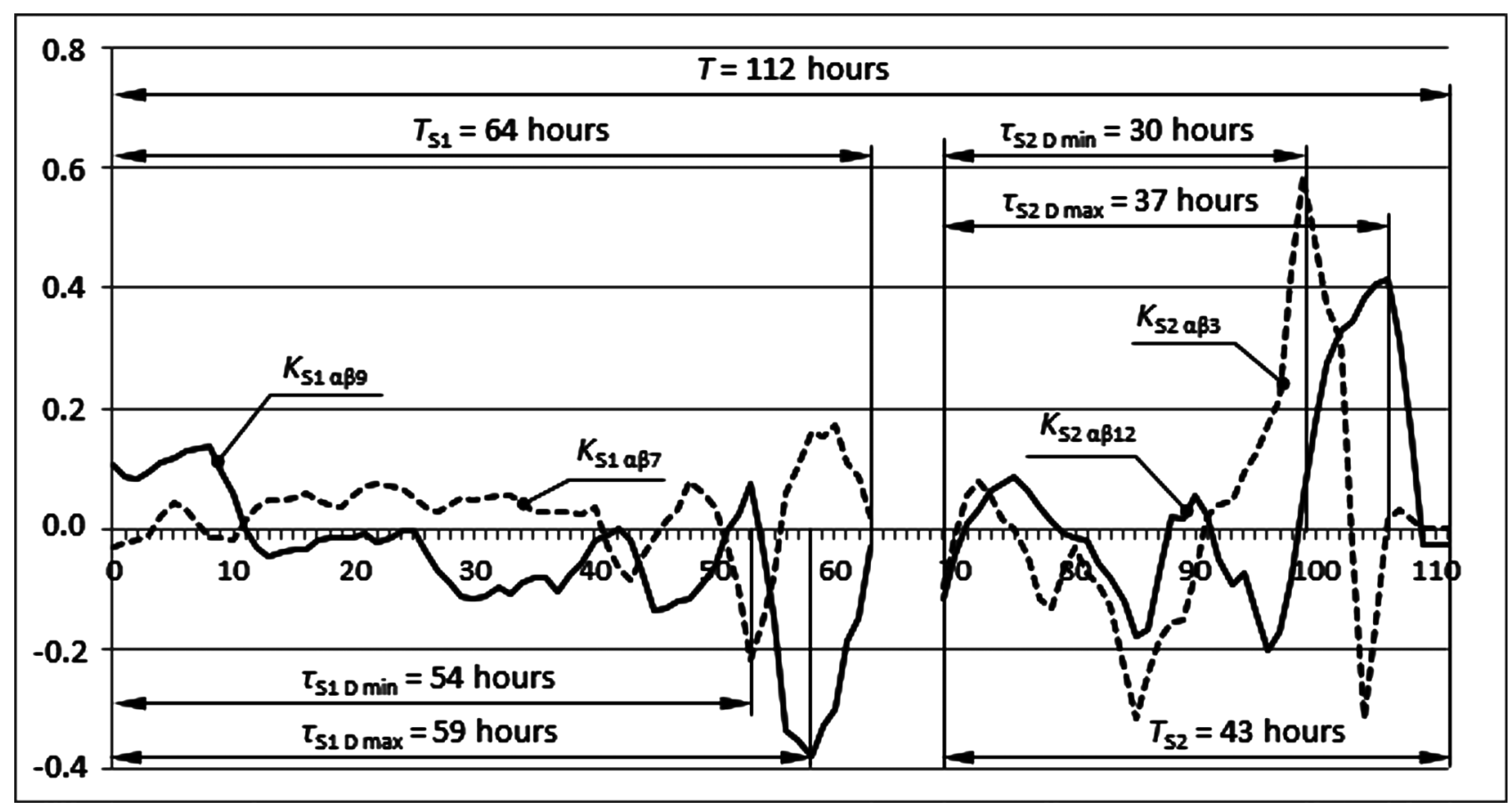

Fig. 4. Correlation functions of the total iron content in the concentrate from its content in the initial ore

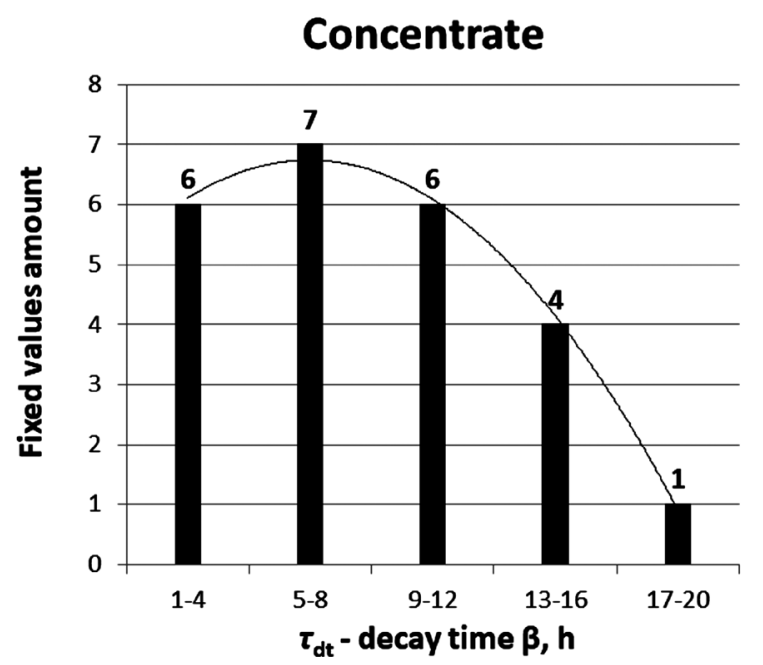

$a$

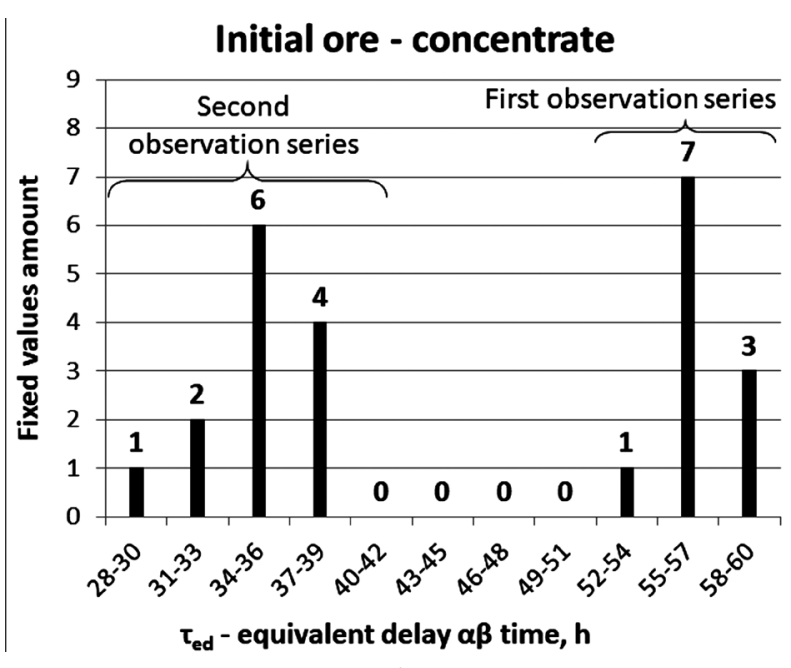

$b$

Fig. 5. Distribution of the decay time and equivalent retardation of the autocorrelation and correlation functions of the total iron content:

$a$-concentrate; $b$ - initial ore - concentrate

content in the concentrate (Fig. 3) was recorded at the twelfth section $\left(K_{S 1 \beta \beta 12}\right)$ and was equal to 4 hours. For the second observation series the minimum decay time was 2 hours. It was fixed at the second section $\left(K_{\mathrm{S} 2 \beta \beta 2}\right)$. The maximum decay time for the first observation series was recorded in the sixth section $\left(K_{S 1 \beta \beta 6}\right)-17$ hours, and for the second - in the thirteenth section $\left(K_{\mathrm{S} 2 \beta \beta 13}\right)-$ 15 hours.

The type of autocorrelation functions made it possible to conclude that all processes are stationary and ergodic: both for the first observation series, and for the second one. All of them are comparable to each other. However, the first series characteristics were completely different from those of the second one. For example, the decay time of the autocorrelation functions of the first series has a relatively stable value (with some acceptable variance). The decay time of the same function for the second observation series has also a stable value but is much smaller than for the first series. This fact indicates that the dressing process is influenced by completely different parameters, conditions and actions. As a result, it is possible to make such a conclusion in the first approximation. In the first series, the disturbances occurred in a natural way, without controlling effects. In the second case, reactions to disturbances were faster and more frequent. The minimum equivalent delay time of the correlation function of total iron content in the concentrate from its content in the original ore (Fig. 4) was observed 
being 54 hours for the first observation series on seventh section $\left(K_{S 1 \boldsymbol{\alpha} \beta \mathrm{\gamma}}\right)$, and for the second series -30 hours on the third section $\left(K_{S 2 \alpha \beta 3}\right)$. The maximum delay equivalent time for the first observation series was recorded at the ninth section $\left(K_{S 2 \alpha \beta 9}\right)$, and for the second series twelfth section (KS2 $\alpha \beta 12$ ), and amounted to 30 and 37 hours, respectively.

An investigation of the correlation functions of the total iron content in the concentrate from its content in the initial ore for the first observation series revealed that there is a close positive correlation between the contents of the useful mineral in the initial ore and the concentrate, which is largely natural. For the second series there is a stable negative correlation between these parameters. This phenomenon may indicate that the formation of technological indicators was simultaneously influenced by factors of ore hardness or dissemination. The order of the observation duration for both series is the same. This made it possible to use all observation series with duration of 43 and 64 hours to construct the distribution functions of the decay time and the equivalent retardation of the autocorrelation and correlation functions of the total iron content in the concentrate. Based on the minimum values (2 and 17 hours) for the construction of the decay time distribution function, the interval is taken equal to the half of the working shift duration (Fig. 5, a), and for the construction of the time equivalent delay distribution function the interval length is equal to three hours (Fig. 5, b). This is due to the fact that the interval length of the equivalent delay time for the first observation series is 9 hours, and for the second observation series -12 hours.

The indicator distribution nature (Fig. 5, b) shows that there are two different sets. But their location order allows making such a conclusion. The second observation series was obtained after an emergency stop and the desire to achieve quickly the required parameters led to frequent management of the technology when the transition process was not completed.

With manual sampling to determine the total iron in the concentrate, the result is obtained after 2 hours. This time is equal to the minimum decay time of the autocorrelation function of the total iron content in the concentrate (Fig. 5, $a$ ). The results of such tests usually come at the shift end, i.e. in 6-7 hours after its beginning. Thus, in the current organization state of determining the total iron content in the concentrate, the operator does not receive information that does not become obsolete by the control action time issuing according to the objective control function over the channel "useful mineral content in the ore - useful mineral content in the concentrate", both for a separate section and for the plant as a whole one. An exit from the collapsed situation can be the automatic control introduction of both the individual section and the factory as a whole, since the time for analysis will be reduced practically to zero.

To estimate the managing possibilities of the wet AG section through the channel "useful mineral content in the ore - useful mineral content in the concentrate", let us compare the decay time of the corresponding correlation functions $\tau_{d t}$ and the equivalent delay time of the correlation function of the total iron content in the concentrate from its content in the initial ore $\tau_{e d}$ (Fig. 5) with the transient process time $T$.

Let us estimate the controlling possibility of the wet ball grinding section along the channel "useful mineral content in the ore - useful mineral content in the concentrate" by comparing the decay time of the corresponding correlation functions $\tau_{d t}$ (Fig. 5, a) with the transient process time $T$.

In accordance with the technological connection scheme of OCP-2 devices, which is shown in Fig. 1 (the third volume of the "Handbook on the ore dressing", edited by Bogdanova O.S.), the transfer function of the whole dressing technological line (DTL) has the form

$$
\begin{gathered}
W(p)=\left(W(p)_{F B 1}+W(p)_{F B 2}\right) W(p)_{1} W(p)_{2} \times \\
\times W(p)_{3} W(p)_{4} W(p)_{5} W(p)_{6} W(p)_{7} W(p)_{11} \times \\
\times W(p)_{12} W(p)_{13} W(p)_{14} W(p)_{F B 3},
\end{gathered}
$$

where $W(p)_{F B 1}=\frac{1}{1-W(p)_{1} W(p)_{2} W(p)_{3 \_1}}$ is the feed-

back operator at the first dressing stage; $W(p)_{F B 2}=$ $=\frac{1}{1-W(p)_{1} W(p)_{2 \_1}+W(p)_{2} W(p)_{3} W(p)_{4} W(p)_{5} W(p)_{F B 3}}$

is the feedback at the second stage; $W(p)_{F B 3}=\frac{1}{W(p)_{F B 3} 1}$

is the feedback between the second and the first dressing stages in which the denominator has the following form

$$
\begin{gathered}
W(p)_{F B 3_{-} 1}=1-\left(W(p)_{6} W(p)_{8} W(p)_{9} W(p)_{10} W(p)_{7 \_1}+\right. \\
+W(p)_{6} W(p)_{7} \times W(p)_{10} W(p)_{11}\left(W(p)_{12 \_1}+\right. \\
\left.\left.+W(p)_{13 \_1} W(p)_{14 \_1}\right)\right) .
\end{gathered}
$$

Members of the complex function (1), which represent the transfer functions of individual devices, have the form

$$
\begin{aligned}
& W_{1}=\frac{1}{0.28 p+1} ; W_{2}=\frac{0.4}{0.001 p+1} ; W_{2_{-} 1}=\frac{0.6}{0.001 p+1} ; \\
& W_{3}=W_{3 \_1}=\frac{0.5}{0.12 p+1} ; \\
& W_{4}=W_{4 \_1}=W_{5}=W_{5 \_1}=\frac{0.5}{0.0055 p+1} \text {; } \\
& W_{6}=\frac{1}{0.18 p+1} ; \quad W_{7}=\frac{0.7}{0.0033 p+1} ; \\
& W_{7_{-} 1}=\frac{0.3}{0.0033 p+1} ; W_{8}=\frac{1}{0.32 p+1} ; \\
& W_{9}=\frac{0.9}{0.001 p+1} ; W_{9 \_1}=\frac{0.1}{0.001 p+1} ; \\
& W_{10}=W_{12}=\frac{0.9}{0.0055 p+1} ; W_{10 \_1}=W_{12 \_1}=\frac{0.1}{0.0055 p+1} \text {; } \\
& W_{11}=\frac{0.8}{p+1} ; W_{11_{-} 1}=\frac{0.2}{p+1} ; W_{13}=W_{14}=\frac{0.95}{0.0055 p+1} ;
\end{aligned}
$$




$$
\begin{gathered}
W_{13 \_1}=W_{14 \_1}=\frac{0.05}{0.0055 p+1} ; W_{15}=\frac{0.95}{0.01 p+1} ; \\
W_{15 \_1}=\frac{0.05}{0.01 p+1} .
\end{gathered}
$$

The coefficients in the above function denominators were obtained on the basis of the ratio of the technological device volumes to their volumetric productivity taken at nominal operating conditions. The device volumes of the technological iron ore dressing line of OCP-2 are known and their numbers correspond to the numbers of the transfer functions in expression (1).

Substituting the device transfer function equations into expression (1) and performing the identical transformations for reducing this expression to the correct algebraic fraction (MathCAD packet), we obtain in the denominator the polynomial, which is the characteristic equation of the differential equation of the transient process in the DTL. The transformation result is obtained as a regular algebraic fraction of a rather high order (the denominator is of more than $20^{\text {th }}$ order with respect to the argument $p$ ). As a result, the transition time $T$ for OCP-2 was determined, which was 20 hours.

Calculation of the transient time by means of transfer functions assumes that the impact was due to volumetric productivity change when the regime parameters of the dressing devices change. When the change occurs due to a deviation in the dressing rating indicators, then in the technological dressing line, static changes occur that change the correlation relationships and can therefore be detected by means of mutual correlation functions.

So $\tau_{d t}<T$ (Fig. 5, a), therefore, by the end of the transient process, the initial information is hopelessly obsolete, and consequently, deviation control from the position of comparing these parameters becomes impossible. On the other hand, the input effect - the change in the dressing characteristics - has not yet manifested itself as a concentrate because $\tau_{e d}>T$ (Fig. 5, b), although the technological process continues to work out the static connection of the valuable mineral content in the concentrate from its content in the initial ore. And the change in the quality of the concentrate continues its trend in accordance with the initial ore quality, which entered the DTL $T$ time ago. Therefore, there is more than enough time to determine the need for management.

Observing the change in the concentrate quality according to the on-duty technological tests (the sampling period $\Delta t$ ), we see a trend in the change of this indicator. And if for $2 \Delta t$ the quality increments have the same sign, then it is possible to make a decision on the expediency of control, but it is required to determine what the initial ore quality was at the moment $T+2 \Delta t$ backward. For a number of observations, we determine the indicator value of the raw material dressing characteristics, simulate technological transformations, and decide on the need for management. Thus, the management is carried out by deviation.

Conclusions and recommendations for further research.
1. Comparison of the decay time and the equivalent retardation of the autocorrelation and correlation functions of the total iron content and the time constant of the processing dressing line showed that the channel "useful minerals content in the ore - the useful mineral content in the concentrate" is possible to control according the deviation of the useful mineral content in a concentrate from a given value.

2. By the correlation functions type between the useful mineral content in the feedstock and concentrate, the following indicative events characterizing the state of the process along the control channel "useful mineral content in the ore - useful mineral content in the concentrate" can be shown:

- a weak correlation or its absence indicates that the process of a useful mineral extraction from the raw material proceeds in a steady state;

- a positive correlation indicates a natural dependence of the concentrate quality on the ore quality;

- negative correlation signals about a transient process, which is related to subjective actions of the technological personnel for supplying the process with the desired direction or for changing the ore grindability;

- the form of the function that does not correspond to the classical notions about it, shows that the effect of management of the dressing process was not neutralized, and the dressing process proceeds in a transitional regime.

3. The next step in determining the indicative events characterized the process state along the control channel "useful mineral content in the ore - useful mineral content in the concentrate" should be spectral analysis and determination of the amplitude-frequency characteristic of the OCP-2.

\section{References.}

1. Sibirtseva, N.B., Potapenko, A.N. and Semiletov, N.A., 2010. Measuring methods of mill load level based on the physical processes of the modern centralized greasing systems. News of the Samara scientific center of the Russian academy of sciences [pdf], 4(3), pp. 694-697. Available at: <http://www.ssc.smr.ru/media/journals/izvestia/2010/2010_4_694_697.pdf> [Accessed 15 April 2017].

2. Andreev, E. E., Nikolaeva, N. V. and Lvov, V. V., 2011. Automatic control method of AG mill operating. Message of the Mining Institute, 192, pp. 61-64. Available at: $<$ https://cyberleninka.ru/article/n/sposob-avtomaticheskogo-upravleniya-rabotoy-melnitsysamoizmelcheniya> [Accessed 7 April 2017].

3. Lazareva, O. V. and Podkamennyy, Yu. A., 2014. Automated management method of diamond ores grinding and classification complex. Herald of the Irkutsk State Technical University, 4(87), pp. 128-132.

4. Zhukov, V. P., Beliakov, A. N., Smirnov, S. F. and Urbaniak, D., 2015. Nonlinear model of hard fuel AG process. Herald of the Ivanov State Power University, 1, pp. 46-50.

5. Enderev, V.A., 2012. Situation and development prospects of control system by an ore mining and processing production in ferrous metallurgy. Modern scien- 
tific researches and innovations [online], 8. Available at: $<$ http://web.snauka.ru/issues/2012/08/16352> [Accessed 26 April 2017].

6. Mladetsky, I. K., Kuvaiev, I. G. and Priadko, N.S., 2017. Control regularities of the useful mineral extraction from ore feed stream with ball. Correlation analysis. Naukovyi Visnyk Natsionalnoho Hirnychoho Universytetu, 4, pp. 91-98.

\section{Виявлення закономірностей керування вилученням корисного мінералу з рудопотоків із самоподрібненням. Частина 1. Кореляційний аналіз}

\section{I. К. Младеиькийㄱ, Я. Г. Куваєв ${ }^{1}$, Н. С. Прядко}

1 - Державний вищий навчальний заклад „Національний гірничий університет“, м. Дніпро, Україна, e-mail: kuvaievig@gmail.com

2 - Інститут технічної механіки НАН України, Державна Космічна Агенція України, м. Дніпро, Україна

Мета. Для виключення оператора з контуру керування процесом збагачення виявити закономірності, що визначають індикативні події, які характеризують стан процесу за каналом керування „вміст корисного мінералу в руді - вміст корисного мінералу в концентраті“ рудозбагачувальною фабрикою із самоподрібненням.

Методика. Кореляційний аналіз показників об'єкта керування - технологічного процесу на збагачувальній фабриці із самоподрібненням.

Результати. За видом і параметрами взаємокореляційних функцій між вмістом корисного мінералу у вихідній сировині й концентраті виділено ряд індикативних подій, що характеризують стан процесу за каналом керування „вміст корисного мінералу в руді - вміст корисного мінералу в концентраті“.

Наукова новизна. Уперше виявлені закономірності управління процесом збагачення шляхом порівняння чисельних значень часу спаду та еквівалентного запізнювання автокореляційних і кореляційних функцій вмісту загального заліза й постійної часу технологічної лінії із самоподрібненням.

Практична значимість. Отримані результати можуть бути використані для побудови автоматичної системи ситуаційного керування процесом збагачення руд чорних і кольорових металів як на окремих секціях із самоподрібненням, так і на фабриках, до складу яких ці секції входять.

Ключові слова: автоматизація, індикативні подіï, система ситуаційного управління, збагачення залізної руди, рудозбагачувальна фабрика з самоподрібненням

\section{Выявление закономерностей управления извлечением полезного минерала из рудопотоков с самоизмельчением. Часть 1. Корреляционный анализ}

\author{
И. К. Младецкий ${ }^{1}$, Я. Г. Куваев ${ }^{1}$, Н. С. Прядко
}

1 - Государственное высшее учебное заведение „Национальный горный университет“, г. Днепр, Украина, e-mail: kuvaievig@gmail.com

2 - Институт технической механики НАН Украины, Государственное Космическое Агентство Украины, г. Днепр, Украина

Цель. Для исключения оператора из контура управления процессом обогащения выявить закономерности, определяющие индикативные события, характеризующие состояние процесса по каналу управления „содержание полезного минерала в руде - содержание полезного минерала в концентрате“ рудообогатительной фабрикой с самоизмельчением.

Методика. Корреляционный анализ показателей объекта управления - технологического процесса на обогатительной фабрике с самоизмельчением.

Результаты. По виду и параметрам взаимокорреляционных функций между содержанием полезного минерала в исходном сырье и концентрате выделен ряд индикативных событий, характеризующих состояние процесса по каналу управления „содержание полезного минерала в руде - содержание полезного минерала в концентрате“.

Научная новизна. Впервые выявлены закономерности управления процессом обогащения путём сравнения численных значений времени спада и эквивалентного запаздывания автокорреляционных и корреляционных функций содержания общего железа и постоянной времени технологической линии с самоизмельчением.

Практическая значимость. Полученные результаты могут быть использованы для построения автоматической системы ситуационного управления процессом обогащения руд чёрных и цветных металлов как на отдельных секциях с самоизмельчением, так и на фабриках, в состав которых эти секции вХодят.

Ключевые слова: автоматизация, индикативные события, система ситуационного управления, обогащение железной руды, рудообогатительная фабрика с самоизмельчением

Рекомендовано до публікації докт. техн. наук B. I. Корсунем. Дата надходження рукопису 15.05.17. 